\title{
IDENTIFIKASI MORFOLOGI DAN KEANEKARAGAMAN KEPITING PADA TIMBUNAN BERBATU DI PANTAI PESISIR MALALAYANG DUA KOTA MANADO
}

\author{
(Identification of Crab Diversity in The Stoney Head of Malalayang Coastal Beach, \\ Manado City)
}

\section{Fatmawati Amin ${ }^{1}$, Darus Saadah J. Paransa ${ }^{2^{*}}$, Medy Ompi ${ }^{1}$, Desy M.H. Mantiri ${ }^{2}$, Farnis B. Boneka ${ }^{2}$, Ockstan Kalesaran ${ }^{3}$}

1. Mahasiswa Program Studi IImu Kelautan, FPIK, UNSRAT Manado

2. Staf Pengajar Program Studi IImu Kelautan, FPIK, UNSRAT Manado

3. Staf Pengajar Program Studi Manajemen Sumberdaya Perairan, FPIK UNSRAT Manado

Penulis korespondensi: Darus Sa'adah Johanis Paransa; darusparansa@unsrat.ac.id

\begin{abstract}
The diversity of crabs in the Malalayang One coast is thought to vary between research locations and limited information on biota that live on rocky, sandy and muddy coastal beaches. Sampling was carried out at low tide at night by capturing directly using a protected hand and for lighting with the help of a flashlight. The collected samples were taken to the Aquaculture Technology Laboratory, Faculty of Fisheries and Marine Sciences, UNSRAT to be identified and for diversity using the Shanon-winer mathematical formula. The results of crabs obtained at five coastal locations on the coast of Malalayang, Manado, with a total of 106 with 7 species, namely Metopograpsus latifrons, Sesarmops impressus, Ocypode kuhlii, Macrophthalmus mareotis depressus, Uca vocans dussumieri, Grapsus Longitarsis and Grapsus albolineatus.
\end{abstract}

Keywords: Crab, Morphology, Diversity, Coastal Ecosystem.

\section{ABSTRAK}

Keanekaragaman kepiting dipesisir Malalayang satu diduga bervariasi diantara lokasi lokasi penelitian dan terbatasnya informasi biota yang hidup di pantai pesisir berbatu, berpasir dan berlumpur. Pengambilan sampel dilakukan pada saat air surut di malam hari dengan menangkap secara langsung menggunakan tangan yang telah di lindungi dan untuk penerangan dengan bantuan senter. Sampel yang telah terkumpul dibawa ke Laboratorium Teknologi Akuakultur Fakultas Perikanan dan IImu Kelautan, UNSRAT untuk diidentifikasi dan untuk keragaman menggunakan rumus matematis Shanonwiner. Hasil kepiting yang didapatkan pada lima lokasi pantai pesisir Malalayang satu Kota Manado dengan total jumlah 106 dengan terdapat 7 spesies yaitu Metopograpsus latifrons, Sesarmops impressus, Ocypode kuhlii, Macrophthalmus mareotis depressus, Uca vocans dussumieri, Grapsus Longitarsis dan Grapsus albolineatus.

Kata kunci: Kepiting, Morfologi, Keanekaragaman, Ekosistem Pantai.

\section{PENDAHULUAN}

Aswandy (2007) melaporkan bahwa kawasan Sulawesi Utara terdiri atas semenanjung, teluk dan pulau-pulau kecil, sehingga disepanjang daerah pesisir dan perairan lautnya dikenal memiliki keanekaragaman hayati laut yang tinggi. Menurut Moosa and Aswandy (1994), salah satu potensi sumberdaya pesisir dan perairan laut dari jenis-jenis krustasea yaitu udang, kepiting, kelomang, stomatopoda. Krustasea memiliki nilai ekonomis dan memiliki nilai ekologis. Bliss and Mantel (1982) menyatakan Scylla serrata memiliki nilai ekonomis tinggi karena dapat dikonsumsi. Selanjutnya Susetiono (2004) mengemukakan di alam juga ditemukan jenis kepiting yang memiliki nilai ekologis seperti kepiting dari genus grapsus sp.

Kehidupan kepiting terbagi atas dua habitat yaitu disepanjang daerah pasang surut dan di perairan laut. Kepiting yang hidup di perairan laut adalah kepiting yang memiliki kaki renang dan kepiting yang hidup di pesisir memiliki kaki jalan (Colin and Arneson, 1995; Poupin and Juncker, 2010). Selanjutnya menurut Poupin and Juncker (2010), daerah pesisir mangrove dan pantai berpasir, umumnya ditemukan kepiting dari genus Aulocolambrus sp. Rhinolambrus sp. Pilumnus sp. Thalamita sp. Scylla sp. 
Neosarmatium sp. Perisesarma sp. Uca sp. dan Macrophthalmus sp. Ocypode sp. Cydograpsus sp. Pseudograpsus sp. Portunus sp. Leucosia sp. Urnalana sp. Menurut Araujo (2004), kepiting yang hidup di daerah berbatu terdapat sembilan jenis spesies kepiting yaitu: Grapsus adscensionis, G. albolineatus Latreille, $G$. fourmonoiro Crosnier, G. granulosus, $G$. grapsus, G. huzardi, G. intermedius, G. longitarsis Dana dan $G$. tenuicrustatus.

Pantai pesisir Malalayang dua terletak di Manado Kecamatan Malalayang dua dengan ekosistem pantai berpasir, berbatu dan berlumpur, sehingga diasumsikan memiliki keanekaragaman hayati laut secara ekologis. Keberadaan kepiting pada tempat penelitian dapat ditentukan Indeks keanekaragaman melalui indikator jumlah kepiting yang menetap di lokasi tersebut. Suatu komunitas tidak akan memiliki indeks keanekaragaman yang tinggi apabila didalam komunitas tersebut terdapat satu atau lebih yang mendominasi Soegianto (1994). Terkait kurangnya informasi mengenai keberadaan keanekaragaman kepiting di wilayah pantai pesisir Malalayang. Maka penelitian ini bertujuan untuk Mengidentifikasi morfologi kepiting yang di tangkap di pantai pesisir Malalayang dua dan menghitung keanekaragaman kepiting di pantai pesisir Malalayang dua.

\section{METODE PENELITIAN}

\section{Lokasi Penelitian}

Di daerah pasang surut pantai pesisir Malalayang dua, Kecamatan Malalayang dua Kota Manado Provinsi Sulawesi Utara Pengambilan sampel terdapat lima tanggul dan ke lima tanggul tersebut terdapat pantai pesisir berbatu, berpasir dan berlumpur yang dijadikan sebagai lokasi pengambilan sampel kepiting. Berdasarkan Gambar 1, Lokasi 1 memiliki ciri habitat berpasir, berbatu dan terdapat sedikit genangan air laut pada saat pasang tinggi. Ditemukan aliran air yang yang bersumber dari pemukiman warga. Tanggul di lokasi tersebut berfungsi sebagai tempat bersandar perahu nelayan. Lokasi 2, memiliki ciri habitat berbatu- berpasir dengan terdapat sedikit genangan air laut dan berfungsi sebagai tempat merapat kapal nelayan. Lokasi 3, memiliki ciri habitat berpasir, berbatu dan berlumpur, pada lokasi ini di terdapat satu satu pohon mangrove dewasa dan ditumbuhi beberapa pohon mangrove lainnya yang baru ditanam dengan substrat yang sedikit kering. Lokasi 4, memiliki ciri habitat berbatu, berpasir dan berlumpur serta ditumbuhi beberapa pohon mangrove dengan terdapat sedikit genangan air laut. Lokasi 5 memiliki ciri-ciri habitat berbatu, berpasir, berlumpur dan sedikit berkerikil serta ditumbuhi satu pohun mangrove dewasa dan lokasi penelitian ini dengan titik koordinat Longitude: $124^{\circ} 47.850^{\prime} \mathrm{E}$ dan Latitude: $1^{\circ} 27.600^{\prime} \mathrm{N}$ (Gambar 1).
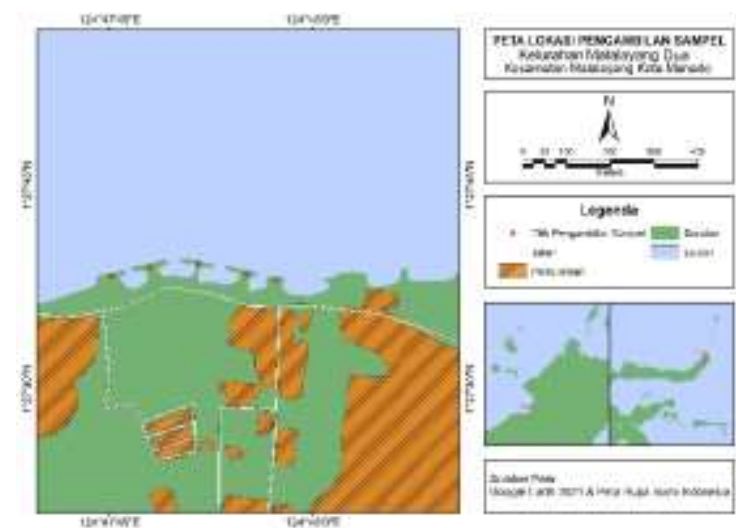

Gambar 1. Lokasi Pengambilan Sampel di Pantai Pesisir Kecamatan Malalayang Dua (Google Earth dan Peta Rupa Bumi Indonesia).

\section{Pengambilan dan penanganan sampel}

Pengambilan sampel kepiting dilakukan dalam lima kali pengambilan pada saat surut terendah di malam hari menggunakan bantuan cahaya dari senter dengan menyusuri masing-masing lokasi timbunan berbatu secara bersamaan selama 1 jam. Penangkapan kepiting mengikuti dari hasil penelitian Paransa (2019) bahwa kepiting ditangkap dengan tangan secara langsung menggunakan sarung tangan. Hasil tangkapan kepiting dari lima lokasi tersebut dimasukkan pada masing-masing ember yang berisi sedikit air laut agar sampel tidak mati. Selanjutnya sampel dibawa ke Laboratorium Teknologi Akuakultur Fakultas Perikanan dan IImu Kelautan, UNSRAT untuk diidentifikasi. Identifikasi mengunakan panduan 
Majchacheep (1989), Poupin and Juncker (2010), Poore (2004), Hogarth (2007), Naderloo (2017), Wilkens (2015), dan WoRMS (2021).

\section{Analisis Data}

\section{Indeks Keanekaragaman}

Dalam mencari nilai keanekaragaman digunakan rumus indeks Shanon-winer (1949) dalam Ulfah (2019) sebagai berikut:

$$
\mathrm{H}^{\prime}=-\sum_{i=1}^{5} \mathrm{Pi} \ln \mathrm{Pi}
$$

Keterangan $\mathrm{H}^{\prime} \quad$ : Indeks Shannon-Wiener

individu suatu spesies

ni : Jumlah

individu dari semua spesies

$\mathrm{N}:$ Jumlah

\section{Indeks Dominasi}

Indeks dominasi di gunakan untuk menentukan nilai yang dominan dari oranisme pada suatu komunitas. Rumus yang di gunakan dikenal dengan indeks Simpson:

$$
C=\Sigma(\mathrm{Pi})^{2}
$$

Dimana $(\mathrm{C})=$ Indeks Dominansi, $\mathrm{Pi}$

kategori Ulfah (2019) yaitu: $0<\mathrm{C}<0,5=$ Dominasi Rendah.

$5<\mathrm{C} 0,75=$ Dominasi Sedang .

$0,75<C 1,0=$ Dominasi Tinggi.

\section{HASIL DAN PEMBAHASAN}

\section{Morfologi Sampel}

Kepiting yang berhasil ditangkap di lima lokasi pantai pesisir Malalayang Dua, Kecamatan Malalayang Kota Manado Provinsi Sulawesi Utara di peroleh 106 sampel kepiting dengan terdapat 7 spesies, seperti yang tampak pada (Tabel $1)$.

Tabel 1. Spesies yang ditemukan di pantai pesisir Malalayang dua, Kecamatan Malalayang Kota Manado Provinsi Sulawesi Utara

\begin{tabular}{|c|c|c|c|c|c|c|}
\hline no & $\begin{array}{c}\text { Jenis-jenis } \\
\text { spesies }\end{array}$ & \multicolumn{1}{|c|}{ Ciri-ciri } & \multicolumn{1}{|c|}{ Lokasi penelitian } \\
\cline { 3 - 7 } & $\begin{array}{l}\text { Metopograpsus } \\
\text { latifrons (White, } \\
1847)\end{array}$ & $\begin{array}{l}\text { Dengan ciri empat pasang kaki jalan berwarna } \\
\text { coklat tua serta terdapat bercak putih yang tidak } \\
\text { beraturan dan juga terdapat bulu-bulu halus pada } \\
\text { bagian daktilus, propodus dan karpus. Pasangan } \\
\text { kaki jalan ke tiga paling panjang diantara pasangan } \\
\text { kaki jalan lainnya dan bagian merus yang paling } \\
\text { lebar. sepasang capit yang sama besar berwarna } \\
\text { coklat muda dengan ujung capit berwarna putih } \\
\text { kecoklatan. Pada bagian propodus dan carpus } \\
\text { ditemukan adanya bintik-bintik kasar pada capit } \\
\text { (Majchacheep, 1989., Poore, 2004 dan WoRMS, } \\
\text { 2021) }\end{array}$ & $\mathbf{2}$ & $\mathbf{3}$ & $\mathbf{4}$ & $\mathbf{5}$ \\
\hline
\end{tabular}




\begin{tabular}{|c|c|c|c|c|c|c|c|}
\hline 2 & $\begin{array}{l}\text { Sesarmops } \\
\text { impressus }(\mathrm{H} . \\
\text { Milne Edwards, } \\
1837)\end{array}$ & $\begin{array}{l}\text { Ciri karapas berwarna coklat kehijauan dan } \\
\text { terdapat corak segiempat berwarna kekuningan. } \\
\text { Bagian frontal regiont terdapat empat lobus, } \\
\text { memiliki sepasang capit yang sama besar, } \\
\text { dibagian daktilus berwarna keunguan dan capit } \\
\text { (daktilus) pada bagian berwarna kekuningan. } \\
\text { Merus pada pasangan kaki jalan nomor tiga } \\
\text { terdapat benjolan berwarna abu-abu dan } \\
\text { pasangan daktilus kaki jalan berwarna kekuningan } \\
\text { dengan ujung yang tajam. Pasangan merus kaki } \\
\text { jalan bercorak batik dengan kecoklatan, } \\
\text { berdasarkan panduan Poore (2004), Ng dkk(2020) } \\
\text { dan WoRMS (2021) }\end{array}$ & $x$ & $x$ & $\checkmark$ & $x$ & $x$ \\
\hline 3 & $\begin{array}{l}\text { Ocypode kuhlii } \\
\text { (De Haan, 1835) }\end{array}$ & $\begin{array}{l}\text { ciri dorsal karapas berbentuk persegi dengan } \\
\text { berwarna hitam terdapat bintik tidak beraturan } \\
\text { dengan warna kecoklatan, memiliki sepasang mata } \\
\text { yang menjulang ke atas. Memiliki sepasang capit } \\
\text { yang dimorfit (capit kiri lebih besar dibandingkan } \\
\text { dengan capit kanan), dengan warna coklat muda } \\
\text { dan dibagian ujung capit berwarna putih serta } \\
\text { terdapat bulu halus. Memiliki empat pasang kaki } \\
\text { jalan yang sama panjang dengan bercorak coklat } \\
\text { yang tidak beraturan serta pada bagian merus } \\
\text { berbentuk seperti tabung, terdapat bulu halus pada } \\
\text { bagian kaki jalan pertama yang terletak pada } \\
\text { bagian daktilus dan propodus. Kaki jalan yang } \\
\text { paling panjang terpada pada bagian ke empat, } \\
\text { berdasarkan Poupin and Juncker (2010), Poore } \\
\text { (2004), Hayou (2015) dan WoRMS (2021) } \\
\text { ditemukan teridentifikasi sebagai Ocypode kuhlii } \\
\text { (De Haan, 1835) }\end{array}$ & $\checkmark$ & $\checkmark$ & $x$ & $x$ & $x$ \\
\hline 4 & $\begin{array}{l}\text { Macrophthalmus } \\
\text { mareotis } \\
\text { depressus } \\
\text { (Ruppell, 1830) }\end{array}$ & $\begin{array}{l}\text { dengan warna coklat dan bentuk persegi. Bagian } \\
\text { dorsal (posterolateral) adanya tuberkel (tonjolan } \\
\text { tonjolan kecil) yang bercorak garis putih berbentuk } \\
\text { segitiga. Memiliki sepasang mata yang menjulang } \\
\text { keatas dengan tangkai berwarna coklat muda dan } \\
\text { mata berwarna cklat tua. Pasangan kaki jalan } \\
\text { berwarna coklat, pasangan pertama dan kedua } \\
\text { kaki jalan bagian propodus berwarna kemerahan } \\
\text { serta pada bagian merus terdapat bulu-bulu halus } \\
\text { (setae). Merus pada pasangan kedua dan ke tiga } \\
\text { berukuran lebih besar dibanding pasangan merus } \\
\text { lainnya serta pasangan kaki jalan ke empat } \\
\text { berukuran paling kecil. Pasangan daktilus memiliki } \\
\text { duri duri tajam dan berwarna kemerahan. Memiliki } \\
\text { sepasang capit berukuran kecil memanjang } \\
\text { dengan sedikit melengkung dengan ujung spatula } \\
\text { datar, merujuk pada Naderloo (2017), Aziz dan } \\
\text { Saher (2016) dan WoRMS (2021), spesies kepiting } \\
\text { yang ditemukan teridentifikasi sebagai } \\
\text { Macrophthalmus mareotis depressus (Ruppell, } \\
\text { 1830) }\end{array}$ & $x$ & $x$ & $\checkmark$ & $x$ & $x$ \\
\hline
\end{tabular}




\begin{tabular}{|c|c|c|c|c|c|c|c|}
\hline 5 & $\begin{array}{l}\text { Uca vocans } \\
\text { dussumieri }(\mathrm{H} . \\
\text { Milne Edwards, } \\
\text { 1852) }\end{array}$ & $\begin{array}{l}\text { ciri dorsal karapas melengkung memanjang dan } \\
\text { menyempit pada bagian bawah berbentuk } \\
\text { trapesium berwarna coklat. Memilki sepasang } \\
\text { mata majemuk yang terletak ditangkai mata } \\
\text { panjang. Empat pasang kaki jalan yang bagian } \\
\text { daktilus, propodus dan karpus berwarna oranye, } \\
\text { sedangkan bagian merus berwarna coklat tua. } \\
\text { Bagian kaki jalan yang paling panjang terdapat } \\
\text { pada bagian ketiga. Setiap ujung pasangan kaki } \\
\text { jalan dilengkapi dengan bulu-bulu halus. ukuran } \\
\text { capit sebelah kanan lebih besar dibandingkan capit } \\
\text { sebelah kiri, pada bagian polleks berwarna kuning } \\
\text { oranye dan bagian daktilus berwarna putih serta } \\
\text { terdapat bintik kasar pada bagian manus } \\
\text { berdasarkan Poupin and Juncker (2010), Hogarth } \\
\text { (2007) dan WoRMS (2021), teridentifikasi sebagai } \\
\text { Uca vocans dussumieri (H. Milne Edwards, 1852) }\end{array}$ & $x$ & $x$ & $\checkmark$ & $\checkmark$ & $x$ \\
\hline 6 & $\begin{array}{l}\text { Grapsus } \\
\text { longitarsis (Dana } \\
1851 \text { ) }\end{array}$ & $\begin{array}{l}\text { Ciri karapas berbentuk margin lateral subparallel } \\
\text { dengan permukaan karapas hampir halus, dorsal } \\
\text { karapas berwarna gelap terdapat garis linear } \\
\text { berwarna putih. Memiliki empat lobus diantara } \\
\text { mata dengan sepasang mata berwarna hitam. } \\
\text { Memiliki empat pasang kaki jalan berwarna hitam } \\
\text { kemerahan serta terdapat bulatan bercorak putih } \\
\text { yang tidak beraturan. pasangan kaki jalan yang } \\
\text { terpanjang terdapat pada bagian ketiga. Memiliki } \\
\text { sepasang capit yang sama besar berwarna hitam } \\
\text { kemerahan dengan ujung capit berwarna putih, } \\
\text { serta terdapat duri putih pada bagian propodus, } \\
\text { menurut Poore (2004), Poupin dan Juncker (2010), } \\
\text { WoRMS (2019) kepiting yang ditemukan } \\
\text { teridentifikasi sebagai kepiting Grapsus longitarsis } \\
\text { (Dana, 1851) }\end{array}$ & $x$ & $\checkmark$ & $x$ & $x$ & $x$ \\
\hline 7 & $\begin{array}{l}\text { Grapsus } \\
\text { albolineatus } \\
\text { (Latreille in } \\
\text { Milbert, 1812) }\end{array}$ & $\begin{array}{l}\text { Ciri-ciri dorsal karapas tersusun garis liner } \\
\text { berwarna hijau kehitaman dengan bentuk karapas } \\
\text { konveks sirkular. Konveks sirkular yaitu karapas } \\
\text { bagian posterior tampak cembung dengan terdapat } \\
\text { garis kuning pada pertengahan karapas. memiliki } \\
\text { empat pasang kaki jalan berwarna coklat dengan } \\
\text { corak bintikan secara acak yang berwarna } \\
\text { kehijauan dan pasangan kaki jalan ke empay yang } \\
\text { paling panjang. Pasangan kaki jalan bagian merus } \\
\text { terdapat bintikan oranye dan pada bagian daktilus } \\
\text { berwarna coklat terdapat duri- duri halus. } \\
\text { Sepasang kaki jalan pertama termodifikasi sebagai } \\
\text { sepasang capit dengan yang sama besar dan } \\
\text { memiliki corak yang dengan pasangan kaki jalan. } \\
\text { Memiliki sepasang mata berwarna berwarna ungu } \\
\text { serta terdapat empat lobus di antara pertengahan } \\
\text { mata, menurut Paransa et. al. (2019), dan Poupin } \\
\text { and Juncker (2010), dikonfirmasi WoRMS (2021), } \\
\text { kepiting ini teridentifikasi sebagai Grapsus } \\
\text { albolineatus (Latreille in Milbert, 1812) }\end{array}$ & $\checkmark$ & $\checkmark$ & $\checkmark$ & $\checkmark$ & $\checkmark$ \\
\hline
\end{tabular}


$(\checkmark)$ : ditemukan/ada; (x) : tidak ditemukan

Spesies Grapsus albolineatus (Latreille in Milbert, 1812) dan Grapsus longitarsis (Dana, 1851) banyak ditemukan menghuni habitat berbatu. Tan dan $\mathrm{Ng}$ (1988) dan $\mathrm{Ng}$ dan Sivasothi (1999) menyatakan kepiting dari family Grapsisdae biasanya ditemukan merayap di permukaan atau masuk kedalam lubang berbatu dan mangrove, dan keluar khususnya malam hari. Kepiting Grapsidae

Spesies kepiting Uca vocans dussumieri $(\mathrm{H}$. Milne Edwards, 1852); Metopograpsus latifrons (White, 1847) dan Sesarmops impressus (H. Milne Edwards, 1837) hidup pada habitat berlumpur. Hal ini sesuai dengan pernyataan Pratiwi dan Widyastuti (2013), kepiting yang biasa ditemukan di ekosistem mangrove berasal dari family Grapsidae, Sesarmidae dan Ocypodidae. Menurut pratiwi (2009), ekosistem mangrove merupakan daerah peralihan antara darat dan laut sehingga memiliki perbedaan sifat lingkungan yang tinggi menyebabkan kepiting harus beradaptasi dengan lingkungannya. Kalor $d k k$ (2018), kepiting dari family sesarmidae cukup menonjol dalam perilaku yang mampu memanjat memanjat akar dan batang mangrove serta berdiam didalam lubang batang mangrove. Saputri (2019) menyatakan ekosistem mangrove memiliki produktivitas yang tinggi, karena ekosistem tersebut mampu menompang keanekaragaman jenis biota di perairan.

Spesies kepiting Ocypode kuhlii (De Haan, 1835) dikenal sebagai kepiting hantu ditemukan hidup pada habitat berpasir. Pratiwi (2019) menyatakan kepiting ini memiliki habitat pantai berpasir yang berhubungan langsung dengan laut. Dilanjutkan oleh Sunaryo (2012), liang digunakan sebagai tempat berlindung dan mencari makan. Denis et al., (2011), kepiting hantu menyukai bangkai biota dan limbah makanan manusia, sehingga kepiting hantu dapat dijadikan indikator bagi kesehatan ekosistem. Schlacher et al. (2011) menyatakan kegitan wisatawan di pantai berpengaruh terhadap kepiting hantu, dikarenakan kegiatan yang berada dipantai menggangu sarang, kelangsungan hidup kepiting hantu dan beradaptasi dengan cara naik keatas batu dan permukaan yang licin. Laili dan Parsons (2006) menyatakan kepiting dari famyly grapsidae memiliki kemampuan yang bergerak dan melompat dengan cepat di bebatuan pantai pesisir yang terhempas ombak. Dilanjutkan oleh Paransa (2019), bahwa kepiting batu memakan alga berfilamen yang ada di atas permukaan bebatuan.

proses rantai mankanan pada ekosistem tersebut. Elfandi dkk (2018), perkembangbiakan dari kepiting ini juga terganggu, dimana susah dalam melakukan kegiatan perkawinan, karena kondisi lingkungan tidak sesuai dengan kebutuhan mereka. Kepiting Hantu memiliki kriteria tertentu untuk dapat bertahan hidup di ekosistemnya.

\section{Macrophthalmus}

(Mareotis) depressus (Ruppell, 1830) spesies dari kepiting ini ditemukan pada habitat berlumpur-berpasir. Aziz dan Saher (2016), kepiting ini menghuni habitat berlumpur berpasir sehingga sebagai pemakan endapan yang dalam lumpur. Rahayu dan Setyadi (2009), habitat dari kepiting ini sangat mudah dikenal seperti lubang yang terbuka berbentuk persegi panjang pada substrat berlumpur.

\section{Indeks Keanekaragaman Kepiting}

Keanekaragaman hayati
merupakan variasi organisme yang
ditemukan pada suatu lokasi, dalam hal ini
adalah keanekaragaman jenis kepiting
yang mendiami lokasi pengamatan di
pantai pesisir Malalayang dua (Gambar 2).

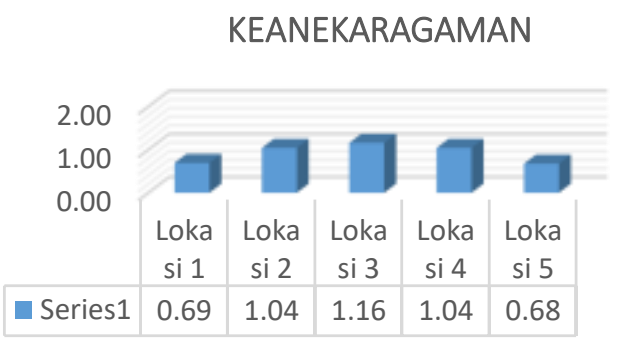

Gambar 2. Nilai Keanekaragaman pada masing masing lokasi pengambilan sampel

$\begin{array}{ccr}\text { Hasil perhitungan } & \begin{array}{r}\text { indeks } \\ \text { keanekaragaman }\end{array}\end{array}$


berdasarkan lokasi, dimana untuk lokasi 3 memiliki indeks keragaman yang lebih tinggi, dibadingkan dengan lokasi lainnya (Gambar 16). Indeks Keanekaragaman $\left(\mathrm{H}^{\prime}\right)$ di lokasi 1 adalah 0.69 , lokasi 2 adalah 1.04, lokasi 3 adalah 1.16, lokasi 4 adalah 1.04 dan lokasi 5 adalah 0.68. Nilai Indeks Keanekaragaman ada di bawah 1 dan 3 lokasi lainnya memiliki indeks keragaman dikategorikan sedang dengan Indeks Keragaman $<1$ dan 3< (Gambar 16). Rondo (2015) menyatakan bahwa jika H' $>$ 3, maka keanekaragaman jenis tergolong tinggi dan jika $1<\mathrm{H}^{\prime}<3$, maka keanekaragaman tergolong sedang.

Nilai keanekaragaman jenis kepiting pada pantai pesisir Malalayang dua dikategorikan sedang dikarenakan pada daerah tersebut mengalami produktivitas yang cukup, kondisi ekosistem cukup seimbang dan tekanan ekologis sedang. Tingginya indeks keanekaragaman pada lokasi 3 dikarenakan keadaan lingkungan sesuai untuk pertumbuhan dan kehidupan kepiting dari spesies Sesarmops impressus ( $\mathrm{H}$. Milne Edwards, 1837), Macrophthalmus mareotis depressus (Ruppell, 1830), Uca vocans dussumieri $(\mathrm{H}$. Milne Edwards, 1852) dan Grapsus albolineatus (Latreille in Milbert, 1812). Hessen (1947) dalam Odum (1996), penyebaran hewan berdasarkan faktof makanan dimana hewan lebih cenderung lebih tinggi pada suatu tempat karena mereka mudah mendapatkan makanan. Kaligis et. al. (2018) menyatakan biota bentik sangat tergantung pada habitat, tidak hanya sebagiai tempat tinggal tetapi juga sebagai sumber makanan mereka. Arsana (2003), ukuran butiran subtrat sangat menentukan sebaran kepiting. Kepiting menunjukkan adaptasi morfologis terhadap kondisi subtrat, serta berkaitan dengan lubang yang akan dibangunnya. Waisaley (2019) dan (Bengen, 1999), kepiting dari genus Uca dapat dijumpai di daerah yang lebih dekat ke daratan, sehingga lebih menyesusaikan diri dengan lingkungan kering. Substrat yang di dominasi dalam penelitian ini yaitu berpasir, berbatu dan berlumpur sehingga sangat mendukung keberadaan kepiting.
Clark (1974) dan Odum (1996) menyatakan bahwa keanekaragaman suatu ekosistem memiliki nilai yang relatif tinggi maka kondisi ekosistem tersebut stabil. Sebaliknya, jika ekosistem terjadi penurunan maka ekosistem tersebut dikatakan dalam keadaan tertekan atau terdegradasi. Indriyanto (2005), menyatakan bahwa keanekaragaman jenis dalam suatu komunitas tergolong tinggi jika komunitas itu disusun oleh banyak jenis, dan dikatakan rendah apabila suatu komunitas itu disusun oleh sedikit jenis dan hanya sedikit jenis yang dominan. Katili (2011) dan Jambo (2021) mengatakan keanekaragaman pada suatu perairan juga dapat menurun karena adanya tekanan secara ekologis. Tinggi rendahnya keanekaragaman juga disebabkan adanya tekanan ekologis berasal dari adanya aktifitas permukiman, transportasi maupun perikanan di sekitar lokasi

\section{Dominasi}

Indeks Dominasi kepiting yang ditemukan pada lokasi penelitian terdapat 7 jenis kepiting yaitu Metopograpsus latifrons (White, 1847), Sesarmorp Sesarmops impressus (H. Milne Edwards, 1837), Ocypode kuhlii (De Haan, 1835), Macrophthalmus mareotis depressus (Ruppell, 1830), Uca vocans dussumieri $(\mathrm{H}$. Milne Edwards, 1852), Grapsus longitarsis (Dana, 1851) dan Grapsus albolineatus (Latreille in Milbert, 1812) (Gambar 3).

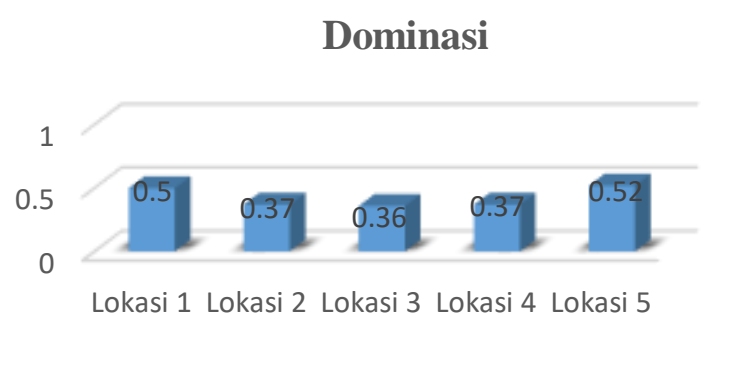

Gambar 3. Indeks Dominasi

Nilai rata-rata indeks dominasi yang ditemukan dalam penelitian ini bervariasi pada tiap lokasi yang tampak pada (Gambar 17). Lokasi 5 memiliki nilai dominasi tinggi adalah 0.52 dikarenakan 
spesies kepiting yang ditemuka hidup bergelombolan mendiami lokasi tersebut, diikuti oleh lokasi 2 dan 4 dengan nilai 0.37 , dilanjutkan lokasi 3 dengan nilai 0.36 dan lokasi 1 dengan nilai 0.5 atau tergolong rendah. Nilai dominasi pada kelima lokasi penelitian dikategorikan renda, menunjukan bahwa kepiting yang ditemukan pada pantai pesesir Malalayng satu tidak ada yang mendominasi. Rando (2015), jika nilai C mendekati 0 berarti tidak ada spesies yang mendominasi dan apabila nilai $\mathrm{C}$ mendekati 1 berarti adanya salah satu sepesies yang mendominasi. Kambey $d k k$ (2015) menyatakan hal ini berarti belum ada terjadi persaingan yang berarti terhadap ruang, makanan, atau tempat hidup bagi organisme tersebut Rina dkk (2018), jika keanekaragaman jenis tinggi pada suatu tempat, maka pada tempat itu tidak terdapat spesies yang dominan, begitu juga sebaliknya apabila keanekaragaman jenis rendah maka ada jenis yang mendominasi.

Menurut Mantiri dkk (2021) kondisi stres biota adalah pengaruah akibat dari aktifitas manusia atau sekitar perairan yang dapat menyebabkab habitat biota terganggu. Convey (2013) dalam Levin (2013), setiap spesies memiliki pengaruh secara langsung salah satu contohnya yaitu predasi dan secara tidak langsung seperti terjadinya perubahan struktur habitat. Kedua hal tersebut akan memberi dampak dan pengaruh terhadap penentuan spesies yang dominan. Nur'aini (2018), Contoh perubahan lain yang terjadinya seperti kenaikan muka air laut dan abrasi menyebabkan perubahan garis pantai dan rusaknya ekosistem mangrove. Widodo (2011) melaporkan bahwa kerusakan habitat dapat mempengaruhi kehadiran spesies dan jumlah individu setiap spesies, yang dapat mempengaruhi variasi Indeks keanekaragaman pada suatu lokasi. Kambey, et al. (2015), daerah yang memiliki ekosistem utama pada pesisir seperti Mangrove, Lamun dan Terumbu karang yang telah dialokasikan menjadi tempat pariwisata, akan memiliki dampak yang signifikan terhadap komunitas yang di dalamnya salah satunya komunitas Echinodermata yang di antara lain Bulu babi dan Bintang laut.

\section{KESIMPULAN}

1. Kepiting yang ditemukan pada lokasi penelitian di pantai pesisir Malalayang satu dengan jumlah 106 sampel, dengan terdapat 7 sepesies yaitu: Metopograpsus latifrons (White, 1847), Sesarmorp Sesarmops impressus $(\mathrm{H}$. Milne Edwards, 1837), Ocypode kuhlii (De Haan, 1835), Macrophthalmus mareotis depressus (Ruppell, 1830), Uca vocans dussumieri $(\mathrm{H}$. Milne Edwards, 1852), Grapsus longitarsis (Dana, 1851) dan Grapsus albolineatus (Latreille in Milbert, 1812)

2. Indeks keanekaragaman kepiting yang tertinggi terdapat pada lokasi tiga dengan nilai 1.16 , sedangkan yang paling rendah pada lokasi satu dan lima adalah 0.69 dan 0.68 .

3. Indeks dominasi kepiting dengan nilai tertinggi pada lokasi lima 0.52 sedangkan yang paling rendah lokasi satu 0.5

\section{DAFTAR PUSTAKA}

Araujo. 2014. The Leaping Behavior Of The Sally Lightfoot Crab Grapsus Grapsus (Crustacea: Dekopoda: Brachyura) At An Oceanic Archipelago. Journal of Research in Biology. 4 (4). 1357-1364 hal

Arsana, I.N. 2003. Komunitas Kepiting (Brachyura: Ocypodidae dan Sesarmidae) di Teluk Lembar, Lombok Barat. Tesis. Yogyakarta: Program Pascasarjana Universitas Gadjah Mada.

Asriyana dan Yuliana. 2012. Produktivitas Perairan. PT Bumi Aksara. 278 hal

Aswandy, I. 2008. Sumberdaya Hayati Di Kawasan Pesisir Teluk Kwandang, Sulawesi Utara. Oseana, Majalah IImiah Semi Populer. 32(3): 9-20 hal

Bliss, D.E., Mantel, L.H. 1982. Systematics, The Fossil Record and Biogeography in The Biologi of Crustacea. Volume 1, New York. America.

Clark, J. 1974. Ecological Considerations For Management of The Coastal Zone. Washington D.C: 
Publications Departement The Concervations Foundation.

Colin. L.P. and C. Arneson. 1995. Tropical Pacific Invertebrates. A Field Guide to the Marine Invertebrates Occuring on Tropical Pacific Coral Reefs, Seagrass Beds and Mangroves. Published by: Coral Reef Press. California. 201 hal

Denis WA, Cephas A, Emmanuel M, Joseph AF. (MEJS). 2011. Rapid Assessmentof Anthropogenic Impacts On Exposed Sandy Beaches In Ghana Usingghostcrabs (Ocypode spp.) as ecological indicators. MekelleUniversity. 3 (2): 93-103

Elfandi, T., Adi, W., dan Syari, I. A. (2018). Kepadatan kepiting hantu (Ocypode) di Pantai Batu Bedaun dan Pantai Air Anyir Kabupaten Bangka. Akuatik: Jurnal Sumberdaya Perairan, 12(1), 1017.

Gustiarisanie A. 2011. Conditions of Marine Phytoplankton in Coastal Areas Meral Karimun regency of Kepulauan Riau Province. Fakultas Perikanan dan Ilmu Kelautan. Riau. Indriyanto. 2005. Ekologi Hutan. Jakarta : Penerbit Bumi Aksara. Jakarta. 210 hal.

Jambo, N. A., Kaligis, E. Y., Kumampung, D. R., Darwisito, S., Schaduw, J. N., dan Pratasik, S. B. 2021. Keanekaragaman Dan Kelimpahan Filum Echinodermata Pada Zona Intertidal Molas Kecamatan Bunaken Kota Manado. Jurnal Pesisir Dan Laut Tropis, 9(2), 104114.

Kaligis, F. E isenbarth J. H, Schillo. D, Dialo. J, Scharberle. T.F, B ohringer. N, Bara. R, Remschussel. S, Koning. G.M dan Wagale, H. 2018. Secound Survey of Heterbranch Seaslugs (Mollusca, Gastropoda, Hetrobranchia) from Bunaken National Prak, North Sulawesi, Indonesia. Mrine Biodiversity Record. 2 hal

Kambey, A.G., U.N.W.J. Rembet dan A.S. Wantasen. 2015. Komunitas Echinodermata di daerah intertidal perairan Pantai Mokupa Kecamatan Tombariri Kabupatem Minahasa. Jurnal IImiah Platax, 3(1), 10-15.

Katili, A.S. 2011. Struktur komunitas Echinodermata pada zona intertidal di Gorontalo. Jurnal Penelitian Pendidikan, 8(1), 51-61hal

Levin, S.A. 2013, Encyclopedia of biodiversity: Second edition. Elsevier Inc., Princeton University, Princeton, New Jersey, USA

Mantiri, I. K., Lintang, R. A., Boneka, F. B., Wagey, B. T., Wantasen, A., dan Ompi, M. 2021. Keragaman Kelinci Laut (Nudibranchia) Di Perairan Laut Sulawesi Utara. Jurnal Pesisir Dan Laut Tropis, 9(2), 86-94.

Moosa, M.K. dan I. Aswandy. 1994. Krustasea Dari Padang Lamun Di Perairan Lombok Selatan. Dalam : Struktur Komunitas Biologi Padang Lamun Di Pantai Selatan Lombok Dan Kondisi Lingkungannya (W. Kiswara, M.K. Moosa Dan M. Hutomo, Eds.) Lipi, Jakarta: 42-51 hal

Nur'aini, A. 2016. Pertumbuhan Dan Produktivitas Kepiting Bakau (Scylla Serrata) Di Perairan Delta Cimanuk, Indramayu, Jawa Barat.

Odum, E. P. 1993. Dasar-Dasar Ekologi. Penerjemahan: Tjahyono Samingan.

Odum, E. P. 1996. Dasar-Dasar Ekologi. Edisi ketiga. Gajah Mada Universitas Press. Yogyakarta.

Paransa, D. S. J. 2019. Komposisi dan metabolisme Pigmen Karotenoid Pada Kepiting Batu Grapsus albolineatus Berdasarkan Waktu Penangkapan. Disertasi. Fakultas Perikanan dan IImu Kelautan Universitas Sam Ratulangi Manado. 151 hal

Paransa, D. S. J., Mantiri, D. M., Lumenta, C., Ompi, M., \& Pratasik, S. B. (2019). Morphological and genetic characteristics of lightfoot crab Grapsus albolineatus Latreille in Milbert, 1812 from Manado Bay, North Sulawesi. Aquaculture, 
Aquarium, Conservation \& Legislation, 12(3), 804-811.

Poupin J,. M. Juncker. 2010. A Guide To The Decapod Crustaceans of The South Pasific. Noumea, New Caledonia. 319 hal

Pratiwi, R., dan Widyastuti, E. 2013. Pola Sebaran dan Zonasi Krustasea di Hutan Bakau Perairan Teluk Lampung. Journal Zoo Indonesia., 22(1):11-21

Rina, S. Abubakar dan Nebuchadnezzar Akbar. 2018. Komunitas Ikan Pada Ekosistem Padang Lamun DanTerumbu Karang Di Pulau Sibu Kecamatan Oba Utara Kota Tidore Kepulauan. Jurnal Enggano, 3(2) 197-210.

Rondo, M. 2015. Metodologi Analisis Ekologi Populasi dan Komunitas Biota Perairan. Program Pascasarjana. Unsrat. Manado. 357 hal.

Saputri, M., dan Muammar, M. (2018). Karakteristik Habitat Kepiting Bakau (Scylla Sp.) Di Ekosistem Mangrove Silang Cadek Kecamatan Baitussalam Kabupaten Aceh Besar, Provinsi Aceh. Biotik: Jurnal IImiah Biologi Teknologi dan Kependidikan, 6(1), 75-80 hal

Schlacher TA, Jager RD, Nielson T. 2011. Vegetation and ghost crabs in coastal dunes as indicators of putative stressors from torism. Elsevier.(11) :284$294 \mathrm{pp}$

Schlacher TA, Jager RD, Nielson T. 2011. Vegetation and ghost crabs in coastal dunes as indicators of putative stressors from torism. Elsevier.(11) : 284-294 hal

Shannon, C. E., dan Weaver, W. 1949. The Mathematical Theory of Communication. Urbana: University of Illinois Press.

Sinyo, Y., Idris, J. 2013. Studi Kepadatan dan Keanekaragaman Jenis Organisme Bentos Pada Daerah Padang Lamun di Perairan Pantai Kelurahan Kastela Kecamatan Pulau Ternate. Jurnal
Bioedukasi. II. No. (1). ISSN : 2301-4678.

Soegianto, A., 1994. Ekologi Kuantitatif: Metode Analisa Populasi dan Komunitas. Airlangga UniversityPress, Surabaya.

Ulfah, M., Fajri, S. N., Nasir, M., Hamsah, K., dan Purnawan, S. 2019. Diversity, evenness and dominance index reef fish in Krueng Raya Water, Aceh Besar. Earth and Environmental Science, 348 (1). 012074

Waisaley, R. S., Kaligis, E. Y., Ompi, M., $\mathrm{RH}$, D., Kumampung, C. A., dan Rangan, J. K. (2019). Inventarisasi Jenis Dekapoda Di Perairan Pantai Kelurahan Tongkaina, Kota Manado. Jurnal Pesisir Dan Laut Tropis, 7(2), 7178 hal

Widodo, 2011. Kajian Pemanfaatan Lahan Bekas Tambang Skala Kecil untuk Pertanian. Jurnal Teknologi Mineral dan Batubara, 7(3):17-26 hal 